\title{
Macroprudential Policy and Financial Stability: The Turkish Case
}

\author{
İlyas Şıklar ${ }^{1} \&$ Aysegül Akça ${ }^{1, *}$ \\ ${ }^{1}$ Faculty of Economics and Administrative Sciences, Anadolu University, Yunus Emre \\ Campus, Eskişehir, Turkey \\ *Corresponding author: Faculty of Economics and Administrative Sciences, Anadolu \\ University, Yunus Emre Campus, Eskişehir, Turkey. Tel: 90-222-335-0580. E-mail: \\ aysegulsahin@anadolu.edu.tr
}

Received: April 10, 2018 Accepted: April 24, 2018 Published: June 10, 2018

doi: 10.5296/rae.v10i2.12979 URL: https://doi.org/10.5296/rae.v10i2.12979

* This study is produced from the master of arts thesis written by Ayşegül Akça under the supervision of İlyas Şıklar at Anadolu University, Graduate School of Social Sciences.

\begin{abstract}
This study aims to analyse the relationship between financial stability and macroprudential policies in Turkey and investigate the effectiveness of macroprudential policies on the financial stability by using the vector error correction model (VECM). Estimates are realized for the 2010-2017 period by using the monthly data. For this purpose, a composite financial stability indicator (FSI) is formed and an estimation model is developed. Banking sector credit concentration, net position of interbank money market, leverage ratio, capital buffers, reserve requirements and foreign currency loan limits are used as macroprudential policy indicators. According the results obtained from VECM model, the ratios which represent concentration of credit and capital buffer provide a favourable contribution to financial stability while the variables representing the leverage ratio and the net position of banking system in interbank money market negatively affect the financial stability. The study concludes that monetary policy should be supported by macroprudential policy instrument to achieve financial stability.
\end{abstract}

Keywords: macroprudential policy, financial stability, VECM. 


\section{Introduction}

2008-2009 global financial crisis has affected Turkey as well as other countries. After the crisis, traditional monetary policy instruments were observed as insufficient and new instruments were started to be used. While it is acknowledged that ensuring price stability is insufficient alone in terms of financial stability, new policies have begun to be established to include the goal of financial stability.

After the global financial crisis, the monetary expansion policies implemented by the central banks of the developed countries increased the capital inflows to the developing countries. With this capital inflow, the currencies of the developing countries gained value, causing the deteriorate major macroeconomic balances of the countries, especially the trade balance. At the end of this process, it has been understood that price stability alone is not sufficient to provide macroeconomic stability. Countries have started to use various macroprudential measures in order to control short-term capital flows which become a major problem in terms of financial stability (Central Bank of the Republic Turkey, 2013).

The purpose of macroprudential policies which have been used for this purpose is to ensure financial stability by preventing systemic risk and to reduce the effects of the crisis on real markets. The aim of financial stability is to reduce the bank failures and the losses due to hot money inflows and outflows, and thus, to limit the effects of instability on the economy. Macroprudential policy instruments use primarily to limit systemic risks. The fundamental purposes of these policies can be listed as follow (Brockmeijer, et al., 2012, p. 8):

- To reduce the financial imbalances,

- To try to stop the post-crises declining economic growth rates, to smooth their sharpness and to reduce negative effect on the economy,

- To determine and study contagion and diffusion risks which put the system in danger as a whole and to investigate the connections among them. Thus, the possibility of disruption of liquid financial transactions for the real economy is minimized.

At the highest level, a desirable model should be conducive to effective mitigation of systemic risk. This requirement can be broken down into the following criteria that are important to ensure successful implementation of macroprudential policy. A model should provide for (Jácome, Nier, Osiński, \& Madrid, 2011, p. 16):

- Effective identification, analysis and monitoring of systemic risk, including through assuring access to relevant information; and using existing resources and expertise.

- Timely and effective use of macroprudential policy tools, by creating strong mandate and powers; enhancing ability and willingness to act; and assuring appropriate accountability.

- Effective coordination across policies aiming to address systemic risk, so as to reduce gaps and overlaps in risk identification and mitigation, while preserving the autonomy of separate policy functions. 


\section{MlMacrothink}

Research in Applied Economics

ISSN 1948-5433

2018, Vol. 10, No. 2

Since the creation of macroprudential policies is still new, these policies are still developing in many countries. Some countries have taken various measures to implement these policy instruments. Some of these measures include the creation of a capital buffer to operate countercyclical, credit guarantee rate, upper limit on debt to income ratios, capital adequacy in various sectors.

The choice of instruments to be included in the macroprudential instrument should be based on a set of desirable features. Generally, such features should include (Viñals, et al., 2011):

- effectiveness in limiting the build-up of systemic risk and creating buffers to be used in periods of stress;

- $\quad$ limited opportunity for arbitrage (regulatory, cross-border);

- $\quad$ aimed at the roots, not the symptoms of systemic risk (notably by inducing private sector agents to internalize the systemic consequences of their decisions); and

- as least distortionary as possible to the financial system and the economy.

The extent of the institutional reform for macroprudential policies, most typically in emerging markets, is constrained by the existing legislation. For instance, the powers and responsibilities of the central bank and its independence are identified in the constitution (especially in Latin America). In emerging markets, the primary macroprudential power is often assigned to central bank (Jácome, Nier, Osiński, \& Madrid, 2011, pp. 9 - 10).

Information on the actual use of macroprudential policies is limited, in part because (the use of) tools are not always clearly identified (some countries have adopted more explicit frameworks, but most have not yet). According to IMF data have been collected from 65 countries, the instruments used in general terms include: caps on loan-to-value (LTV) and debt-to-income (DTI) ratios, limits on credit growth (CG), limits on foreign lending (FC), reserve requirements (RR), dynamic provisioning (DP), and counter-cyclical requirements (CTC). In developed countries, LTV and DTI ratios are used the most, while other policies are rarely used. Emerging markets use more policy instruments and longer than advanced countries and tend to favor more foreign exchange and liquidity related policies (FC, RR), maybe due to their concerns with large and volatile capital flows and related systemic risks (Claessens, 2014, p. 15).

Various factors influence the selection of macroprudential instruments. Emerging market economies are more concerned about systemic liquidity risk and use liquidity measures more often. While developed countries tend to support measures related to loans, they have started to use liquidity measures mostly after the crisis.

The impact and transmission of macroprudential policy are far from being well understood empirically, for three main reasons. First, it is too early to empirically assess the effectiveness of tools that were introduced only over the past few years. Not only are the data needed to conduct empirical research scarce, but there has been very little analysis in the literature on which data are needed for macroprudential policy purposes. Second, empirical work is more difficult in the absence of established models of the interaction between the financial system 
and the macroeconomy. Third, complicating the assessment of the effectiveness of macroprudential tools is that measures are often not taken in isolation, but in combination with other policies. There is therefore a great need of more systematic empirical evaluation of the effectiveness of macroprudential tools employed recently or historically (Galati \& Moessner, 2013, p. 859).

In the limited literature there are some empirical findings that macroprudential policies may contribute to reducing systemic risk and achieving financial instability. Lim et al. (2011) conducted a study using the the data of IMF 2010 survey and showed the use of macroprudential tools such as the loan to value ratio and the debt to income ratio reduce the cyclical dependence of credit growth.

Brockmeijer et al. (2012) found that loan value ratio, debt income ratio, risk weights and reserve adequacy loans were effective in slowing the increase in credit volume and house prices.

Kuttner and Shim (2012) have found similar results by using the data obtained from 57 countries and have determined that the loan value ratio, debt to income ratio are effective in slowing housing prices and mortgage loan growth.

In the study conducted with the data of 13 countries, Wang et al. (2011) have concluded that reducing the loan to value ratio causes a decrease in households' leverage ratio, and therefore, a fall in mortgage risk during housing loan shocks.

Jiménez et al. (2012) have found that macroprudential instruments slow down the fluctuations in credit supply and have a positive effect on the firm level credits.

Most of the studies on macroprudential policies have proven that credit utilization is decreasing and house price increases are slowing along with the use of tools such as loan value ratio, debt income ratio, dynamic provision and credit growth limits. The slowdown in housing price increases suggests that the use of macroprudential policies would help to reduce systemic risk.

In this study our principal aim is to investigate the macroprudential policies on financial stability in Turkey during 2010-2017 period and to make some contributions to the existing scarce empirical literature. Because of discussions in the literature that "multiple goals and multiple tools" could reduce the effectiveness of monetary policy and move away a central bank from it is main target of price stability, the empirical results are particularly important in terms of both developed and emerging markets. Rest of the paper is organized as follows: Part 2 of the study discusses the forming of a composite financial stability indicator as well as the estimation model to be used. While Part 3 mainly analyses the estimation results, Part 4 concludes the study. 


\section{Mll Macrothink}

\section{Model}

Both in emerging economies and developed countries, modern central banks have generally two objectives: (1) providing price stability and (2) maintaining financial stability. Although the objective of price and financial stability is a suitable basis for monetary policy, both objectives are not clearly defined. In addition to the lack of widely accepted definition of financial stability, there is no consensus on the measurement of it. Therefore, in a study which aims to investigate the financial stability, the priority should be given to the development of a measure regarding financial stability.

In order to develop the model in our study, it is necessary to create an indicator of financial stability. For this purpose, a composite financial stability indicator (FSI) which represents the health situation of the financial system is formed. Financial stability indicators are traditionally formed weighted averages of a series of indicators. Naturally, the banking sector should be emphasized as it forms a large part of the financial system in the creation of this indicator. The banking sector is the most important financial sector component in determining credit supply in countries like Turkey.

The FSI is the weighted average of representative indicators of financial system components. These components can be listed as banking sector indicators (BSI), credit market indicators (CMI) and foreign exchange market indicators (EMI). Accordingly, FSI can be written as:

$$
F S I_{t}=w_{F S C}^{0} F S C_{t}
$$

In this equation, $\mathrm{FSC} \equiv\left[B S I_{t}, C M I_{t}, E M I_{t}\right]$ is the financial system component vector and $w_{F S C} \equiv\left[w_{B S I}, w_{C M I}, w_{E M I}\right]$ is the calculated weights vector. Weights can be calculated in various ways, ranging from personal observations or judgments to empirical methods. We will choose the empirical method and we will make the estimation of the following equation for this purpose.

$$
y_{t}=\beta_{0}+\beta_{1} y_{t-1}+\beta_{\text {FSC }}^{\mathrm{n}} \text { FSC }_{t-i}+\xi_{t}
$$

In equation (2), $y_{t}$ represents real economic activity volume and $\beta_{F S C}^{1}$ represents coefficient vector that will be used for calculating the weights with the following equation (3):

$$
w_{F S C} \equiv \frac{1}{i \beta \beta_{F S C}} \beta_{F S C}
$$

The three sectors as FSC components in the construction of the FSI will be considered as:

1. Banking Sector Indicator (BSI): Return on assets ratio 
2. Credit Market Indicators (CMI): 1-year maturity consumer credit interest rate and the total credit volume

3. Exchange Market Indicator (EMI): Foreign exchange rate basket $(0.5 \$+0.5 €)$

The return on assets rate will be calculated as:

$$
\text { ROA }=\frac{\text { Net Profit After Taxes }}{\text { Total Assets }}
$$

In our study, the period of implementation of macroprudential policy in Turkey will be considered the beginning of 2010 . We chose this starting date because we can exclude the $2008 / 2009$ financial crisis from the review period. In this way, it will be possible to observe the effect of macroprudential policies at a time when relatively stable financial conditions occur in the economy. The data used for scaling the calculated indicators should undergo a compliance process. Increasing trends in indicators such as exchange rate and interest rate will cause tightness in financial conditions. For this reason, these type of variables will be included in the model by using their reciprocals. In other words, if you scale such a variable with $\mathrm{X}$, the 1 / $\mathrm{X}$ value should be taken as the basis. On the other hand, the credit volume will be included with the logarithmic level in to the model.

As a second step, variables must be normalized. Since the variables used are expressed in different units, it is only possible to index them by reducing them to the same scale. For this purpose, there are two methods: Statistical normalization and empirical normalization. In this study, empirical normalization method is preferred because this method scales all the numerical values in the relevant time series in the interval $[0,1]$. It is easy to evaluate the change in the relevant time series on this count. Empirical normalization is achieved through the equation below:

$$
X_{i}^{n}=\frac{X_{i}-X_{\min }}{X_{\max }-X_{\min }}
$$

Considering the above-mentioned advantage, empirical normalization method was preferred and the banking sector return on assets ratio, 1 / (interest rate), 1 / (exchange rate basket), credit volume (logarithmic level) series are normalized by using equation (5).

In the process of estimation, the volume of economic activity should be measured by GDP. Since we use monthly data in the estimation, monthly GDP figures are not available. Consequently, we use industrial production index as the proxy for GDP as it shows a high correlation with GDP. On the other hand, since we do not have a prior information about the lag structures of the variables in equation (2), Akaike Information Criteria is used to determine the lag lengths of variables. The Table 1 summarizes the obtained results with some diagnostic tests: 


\section{Al Macrothink}

Table 1. Economic Activity Volume Forecasting Results

\begin{tabular}{lllll}
\hline Variable & Coefficient & Lag & t statistic & Marginal Significance \\
\hline Constant & 0.010 & - & 0.043 & 0.966 \\
$y$ & 0.372 & 1 & 2.129 & 0.037 \\
bsi & 0.040 & 6 & 2.021 & 0.047 \\
cmil & 0.143 & 1 & 2.802 & 0.010 \\
cmi 2 & 0.211 & 1 & 3.650 & 0.001 \\
emi & 0.204 & 3 & 2.993 & 0.004 \\
AdjR & 0.655 & & & \\
F & 4.312 & & & \\
& $(0.000)$ & & & \\
(Prob) & & & & \\
D.W. & 1.861 & & & \\
\hline
\end{tabular}

Explanation of the financial stability indicators obtained from this estimated model and derivation of the weights are given in Table 2.

Table 2. Empirical Weights of Financial Stability Components

\begin{tabular}{clcr}
\hline Component & \multicolumn{1}{c}{ Variable } & Coefficient & Weight \\
\hline$b s i$ & Return on Assets & 0.040 & 0.07 \\
cmi 1 & Interest Rate & 0.143 & 0.24 \\
cmi 2 & Credit Volume & 0.211 & 0.35 \\
emi & Exchange Basket & 0.204 & 0.34 \\
\hline
\end{tabular}

Empirically obtained weights $\left(w_{i}\right)$ are used to calculate the financial stability indicator through the following equation:

$$
\mathrm{FSI}_{t}=w_{\text {FSC }}^{\circ} F S C_{t}
$$

The course of the financial stability indicator obtained for the estimation period can be seen from Figure 1.

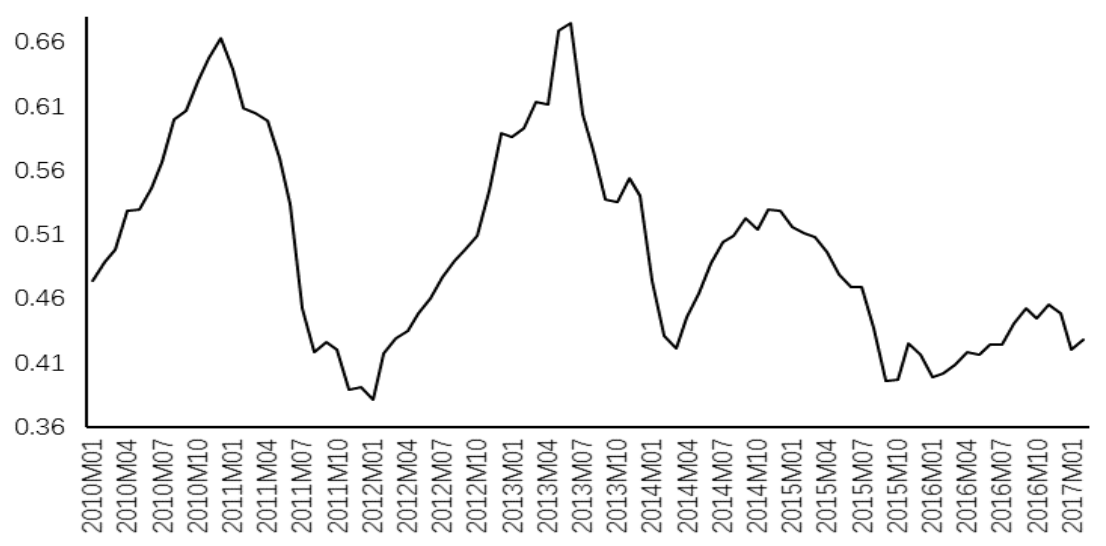

Figure 1. Financial Stability Indicator (2010:01- 2017:02) 


\section{Macrothink}

If the indictor is near to 0 , this will show deterioration in financial conditions, and otherwise when the indicator is near to 1 , this will show positive financial conditions in the economy. In other words, when constructed indicator displays a decreasing trend to zero, financial conditions in the economy indicate a deterioration. On the contrary financial conditions are in positive tendency when the indicator show an increasing trend toward 1.

Following (Cerutti, Correa, Fiorentino, \& Segalla, 2016), we are going to use four macroprudential policy tools with the addition of two mostly tolls conducted by emerging economies. Definitions and contents of these tools are as follow:

(1) Limitation of banking sector credit concentration is measured by the ratio of loans / assets and represented by CONC.

(2) Limitation on interbank money market position is measured by the ratio of "net interbank position/liabilities and is shown by INTER.

(3) Regulation of banking system leverage ratios is measured by assets / equity ratio and shown by LEV.

(4) The banking sector capital buffers is measured by capital / loans ratio and shown by CTC.

(5) Regulation of the banking sector required reserves is measured by the ratio of required reserves / total liabilities and shown by RR.

(6) The limitation of foreign currency debts obtained by the banking sector is measured by the ratio of foreign currency liabilities / total liabilities and shown by FC.

In this study, the course of the above mentioned ratios which are used to express macroprudential policies can be seen from Figure 2 through 7.

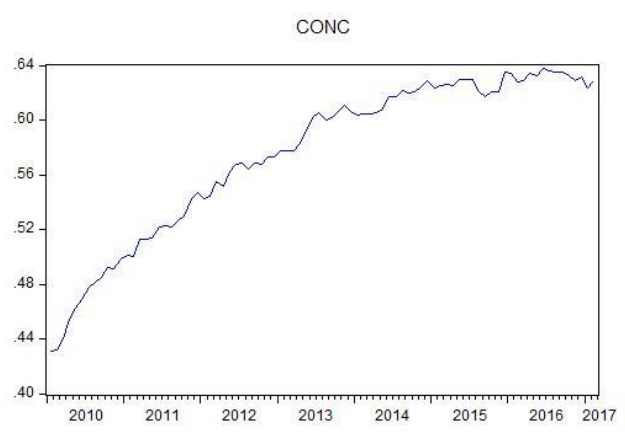

Figure 2. Loans/Assets Ratio

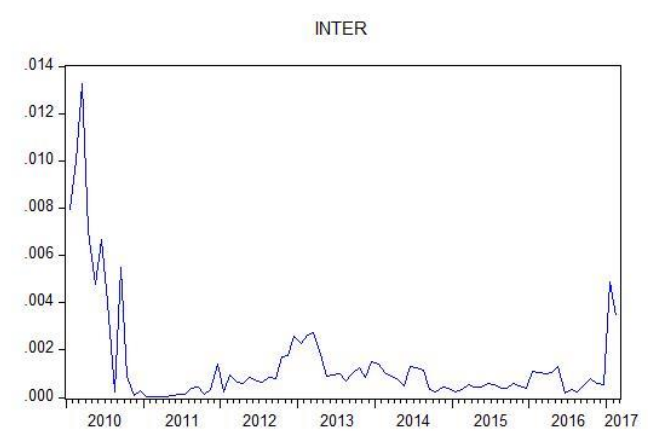

Figure 3. Net Interbank Position/Liabilities 


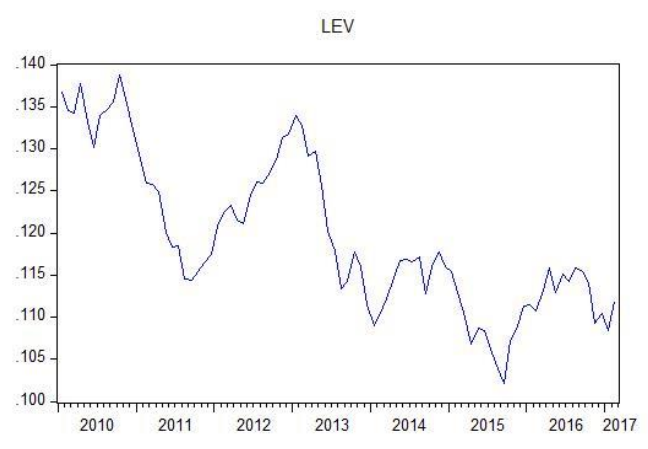

Figure 4. Assets/Equity

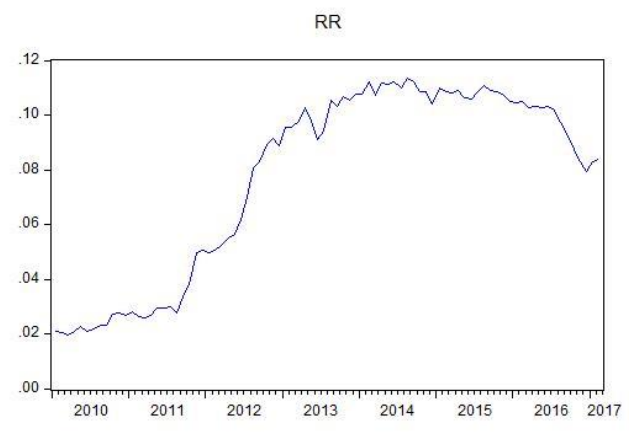

Figure 6. Required Reserves/Total Liabilities

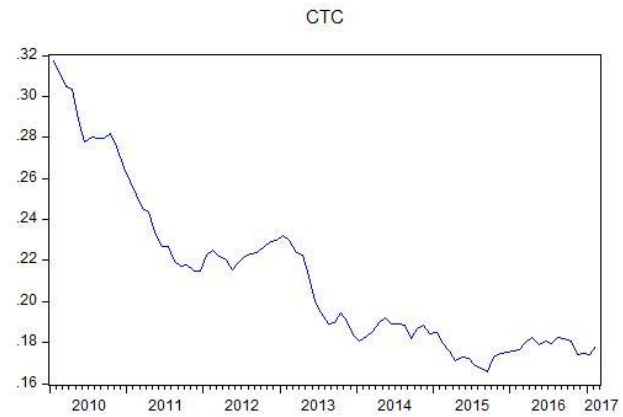

Figure 5. Capital/Loans Ratio

FC

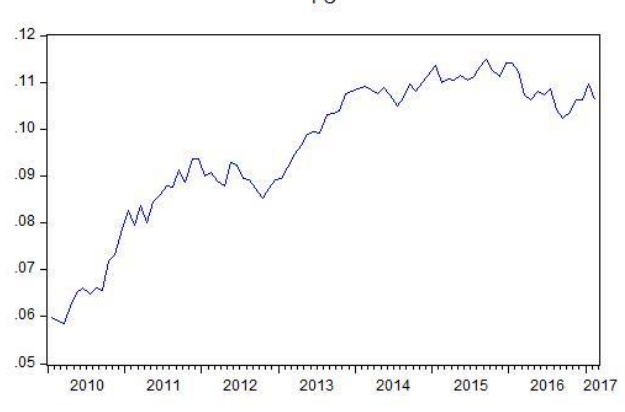

Figure 7. Foreign Currency

Liabilities/Total Liabilities

The ratio of Loans/Assets shown in Figure 2 has an increasing trend throughout the investigation period. This situation indicates that there is a significant credit expansion in Turkey especially in the period of 2010-2014, however the share of the credits within the total assets has entered the stage of pause after this date. According to Figure 3 which shows the share of the banking system's net interbank money market position in total liabilities, interbank money market transactions are quite low except for 2010 and that the system carries mostly net surplus position. The leverage ratio (assets/equity) which is an indicator that directly affects the profitability of the banking system, fluctuated during the period of study. The general trend of the ratio as seen in Figure 4 is downward throughout the study period. The high values of financial leverage that has been accepted as the trigger of 2008 Global Financial Crisis refer to risk level of financial institution undertakes or the financial system as a whole. Especially with the application of minimum capital requirements, it is possible to say that the process of deleveraging in the world financial system is felt in Turkey as well.

According to Figure 5 which shows the capital/loans ratio in the analysing period indicates a decreasing trend in general terms. In a period where the financial leverage shows a decreasing trend and the share of credits in the total assets shows an increasing trend, a decreasing course of capital/loans ratio is quite natural. In the case of diminishing profitability, the factor that leads the banks to stay in the system is possibility to compensate for decreasing profits. Figure 6 shows de facto required reserve ratio realized in the Turkish 


\section{Mll Macrothink}

Banking System. It indicates that the required reserves have increased significantly since 2011. On the one hand, the CBRT gradually increased the required reserve ratios (from 5\% to $7.5 \%$ on average), on the other hand, introduction of the ROM (Reserve Option Mechanism) application from September 2011 was the other factor that increases this ratio. Figure 7 shows the trend of the foreign currency liabilities/total liabilities ratio which is the last macroprudential policy tool we will use to explain financial stability in this study. At the beginning of the analysing period, foreign exchange denominated liabilities with a share of $6 \%$ in total debts rise since 2014 , reaching $11 \%$ and maintaining this level in the following period. This increasing tendency is undoubtedly related to the value of domestic money.

In this part of our work, considering the above explanations, a total of seven variables are used: FSI, CONC, INTER, LEV, CTC, RR, and FC. Descriptive statistics of the time series related these variables for the 2010: January- 2017: February period are presented in Table 3.

Table 3. Descriptive Statistics of the Time Series

\begin{tabular}{lccccccc}
\hline & FSI & CONC & INTER & LEV & CTC & RR & FC \\
\hline Mean & 0.499 & 0.575 & 0.002 & 0.120 & 0.212 & 0.077 & 0.096 \\
Median & 0.489 & 0.602 & 0.001 & 0.117 & 0.195 & 0.094 & 0.101 \\
Maximum & 0.675 & 0.637 & 0.013 & 0.139 & 0.318 & 0.114 & 0.115 \\
Minimum & 0.382 & 0.431 & 0.000 & 0.102 & 0.166 & 0.019 & 0.058 \\
Standard Deviation & 0.077 & 0.058 & 0.002 & 0.009 & 0.039 & 0.034 & 0.016 \\
Skewness & 0.487 & -0.853 & 3.111 & 0.426 & 1.019 & -0.608 & -0.850 \\
Kurtosis & 2.228 & 2.585 & 13.614 & 2.114 & 3.159 & 1.676 & 2.740 \\
Jarque-Bera & 5.541 & 11.045 & 542.421 & 5.407 & 14.975 & 11.580 & 10.592 \\
(Probability) & $0.063)$ & $(0.004)$ & $(0.000)$ & $(0.067)$ & $(0.001)$ & $(0.003)$ & $(0.005)$ \\
Sum & 42.941 & 49.466 & 0.126 & 10.282 & 18.196 & 6.646 & 8.244 \\
Sum of Deviation & 0.505 & 0.287 & 0.000 & 0.007 & 0.128 & 0.100 & 0.021 \\
Squares & & & & & & & \\
Observations & 86 & 86 & 86 & 86 & 86 & 86 & 86 \\
\hline
\end{tabular}

\section{Estimation}

Another aspect that needs to be considered when examining the statistical properties of the time series to be used in an econometric model is the integration feature exhibited by the series. Used time series must be stationary for the relationship among the variables in an econometric model to be meaningful. For this reason, these features of the series must be investigated before proceeding to the next stage. Two commonly used techniques can be mentioned when testing whether the time series carries the stationarity feature (the degree of integration of the time series): Augmented Dickey-Fuller (ADF) test and Phillips-Peron (PP) test. Both test results presented in Table 4 show that the time series used are not stationary at their level, but become stationary at their first differences. This means that all of the time series are characterized by I (1), in other words, they are integrated of order one. 
Table 4. Unit Root Test Results

\begin{tabular}{lcccccc}
\hline Variable & $\begin{array}{c}\text { Lag } \\
\text { Length }\end{array}$ & $\begin{array}{c}\text { ADF } \\
\text { Test }\end{array}$ & $\begin{array}{c}\text { Marginal } \\
\text { Significance }\end{array}$ & $\begin{array}{c}\text { Band } \\
\text { Width }\end{array}$ & PP Test & $\begin{array}{c}\text { Marginal } \\
\text { Significance }\end{array}$ \\
\hline FSI & 1 & 2.318 & 0.169 & 4 & 1.955 & 0.306 \\
$\Delta$ FSI & 0 & 5.587 & 0.000 & 3 & 5.500 & 0.000 \\
CONC & 0 & $2.118^{*}$ & 0.529 & 6 & $2.239^{*}$ & 0.462 \\
$\Delta$ CONC & 0 & 9.232 & 0.000 & 4 & 9.277 & 0.000 \\
INTER & 3 & $3.256^{*}$ & 0.081 & 3 & $2.127 *$ & 0.388 \\
$\Delta$ INTER & 2 & $4.741^{*}$ & 0.000 & 5 & $15.543 *$ & 0.000 \\
LEV & 0 & 1.426 & 0.566 & 4 & 1.605 & 0.476 \\
$\Delta$ LEV & 0 & 8.161 & 0.000 & 3 & 8.216 & 0.000 \\
CTC & 6 & 2.673 & 0.250 & 4 & 1.799 & 0.697 \\
$\Delta$ CTC & 0 & 6.480 & 0.000 & 4 & 6.540 & 0.000 \\
RR & 0 & 1.866 & 0.347 & 3 & 1.733 & 0.411 \\
$\Delta$ RR & 0 & 7.751 & 0.000 & 3 & 7.842 & 0.000 \\
FC & 0 & 2.272 & 0.183 & 3 & 2.370 & 0.153 \\
$\Delta$ FC & 0 & 9.855 & 0.000 & 1 & 9.851 & 0.000 \\
(*) shows inclusion of a time trend. & & & \\
\hline
\end{tabular}

Once we have stated that the time series are integrated, we can consider the model for predicting the relationship among these variables. Accordingly, the model to be estimated can be written as:

$$
X_{t}=\operatorname{VAR}(F S I, C O N C, I N T E R, L E V, C T C, R R, F C)
$$

If no cointegration vector is found as a result of cointegration tests, then the VAR model can be used to analyse the relationship among the group of variables. If we determine the existence of at least one cointegration vector, then the proper estimation method is the VECM. Since we do not have a prior knowledge about the lag structure of the variables, we first applied lag selection criteria as FPE, AIC, SIC and HQ. Although the obtained results are not reported to save space, FPE, AIC and HQ criteria show that the optimal lag length is one month. By using this lag length, applied cointegration tests produce the results presented in Table 5 below: 


\section{Macrothink}

Table 5. Johansen Cointegration Test Results

\begin{tabular}{cccccc}
\hline $\begin{array}{c}\text { Cointegrated } \\
\text { Vector }\end{array}$ & $\begin{array}{c}\text { Eigen } \\
\text { Value }\end{array}$ & Trace Test & Probability & $\begin{array}{c}\text { Maximum } \\
\text { Eigen } \\
\text { Value Test }\end{array}$ & Probability \\
\hline None & 0.541 & $199.070^{*}$ & 0.000 & $65.346^{*}$ & 0.001 \\
At most 1 & 0.428 & $133.724^{*}$ & 0.000 & $46.920^{*}$ & 0.020 \\
At most 2 & 0.328 & $86.804^{*}$ & 0.012 & 33.332 & 0.129 \\
At most 3 & 0.224 & 53.471 & 0.071 & 21.256 & 0.453 \\
At most 4 & 0.205 & 32.215 & 0.100 & 19.272 & 0.199 \\
At most 5 & 0.137 & 12.943 & 0.245 & 12.425 & 0.214 \\
At most 6 & 0.006 & 0.518 & 0.472 & 0.518 & 0.472 \\
(*) indicates the rejection of null hypothesis at the 5\% level of significance \\
\hline
\end{tabular}

The results indicate 3 cointegrating vectors for trace test and 2 cointegrating vectors for maximum eigenvalue test. According to these results, it is possible to say that the non-stationary time series move together towards an equilibrium point in the long run. The normalized coefficients of the resulting cointegrated vector for the Financial Stability Indicator are as follow:

$$
\mathrm{FSI}=-2.651(\mathrm{CONC})+1.067(\mathrm{INTER})+20.555(\mathrm{LEV})-24.319(\mathrm{CTC})+1.801(\mathrm{RR})+15.319(\mathrm{FC})
$$

Considering the above determination, we should estimate the model by using VECM methodology. In order to avoid possible bias, the previously determined lag length is used and the number cointegrated vectors is assumed as two depending the cointegration test results.

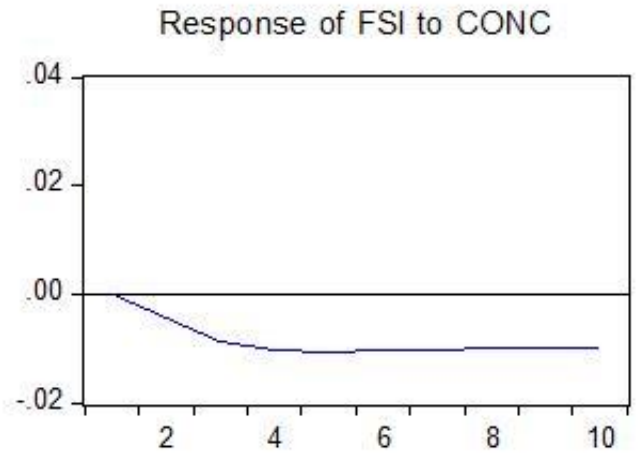

Figure 8. FSI and Credit Concentration

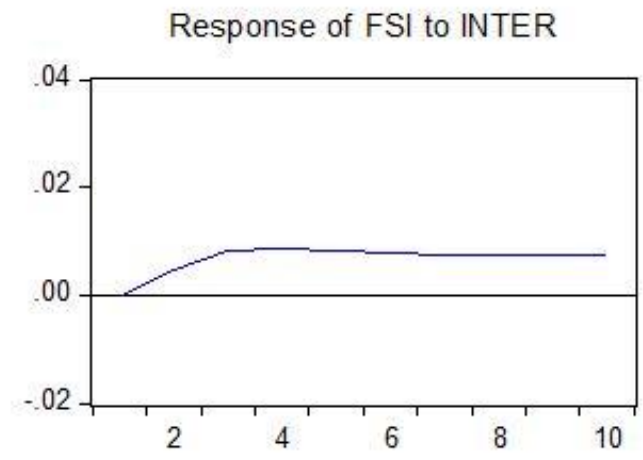

Figure 9. FSI and Money Market Position 


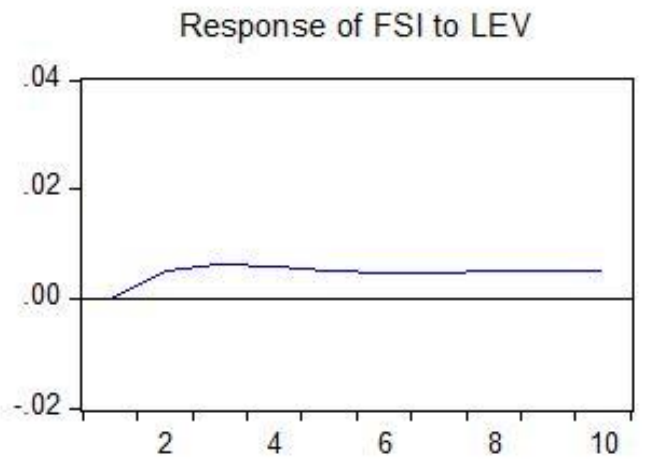

Figure 10. FSI and Leverage Ratio

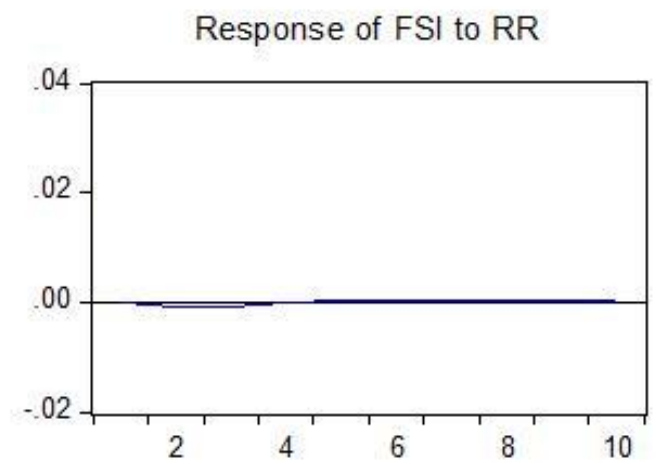

Figure 12. FSI and Required Reserves

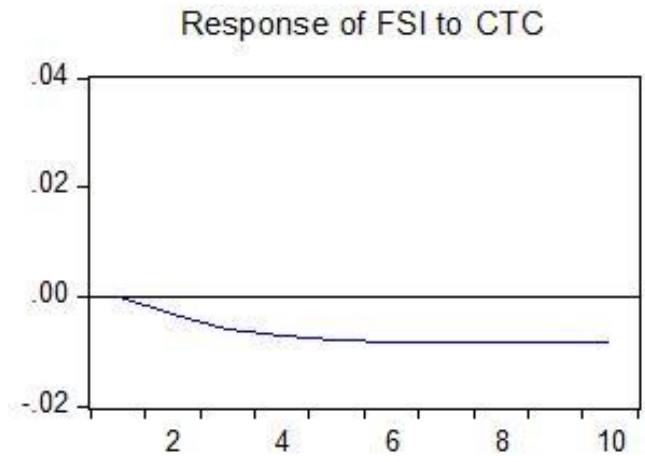

Figure 11. FSI and Capital Buffer

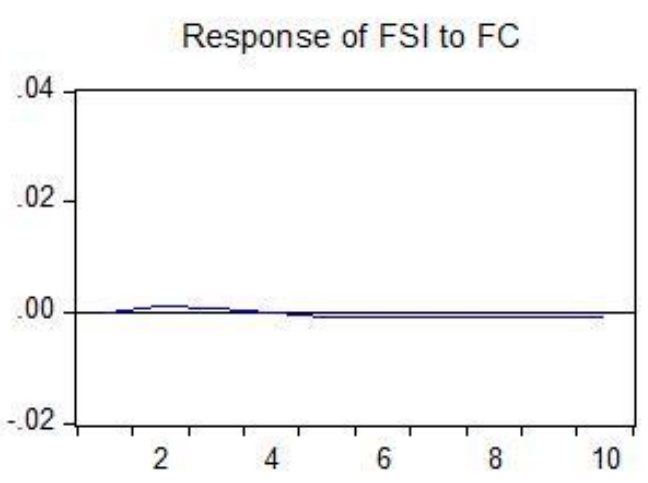

Figure 13. FSI and Foreign Currency Liabilities

It is necessary to consider the impulse response functions shown in Figures 8-13 as the impact on the financial stability of the 1 standard deviation shock that will occur in each macroprudential instrument.

The macroprudential tool we use to represent credit concentration in the banking system (CONC) affects financial stability positively. A positive shock to be observed in this variable according to Figure 8 affects the financial stability indicator in the opposite direction, and this effect is permanent throughout the year. The indicator of banks money market position (INTER) and the indicator of financial stability change in the same way. A positive shock (increasing borrowing tendency due to increased reserve demand) in the net money market position causes deterioration in the financial stability indicator. According to Figure 9, this deterioration continues throughout the year. Figure10 indicates that a positive shock to the banking system leverage ratio will negatively affect financial stability. Although increasing leverage ratio increases the banking system's profitability, it also increases the risk of capital inadequacy; therefore, it is one of the most important indicators for the whole financial system. Impulse- response function in Figure10 confirms this importance in the Turkish case. In other words, the fact that deleveraging process experienced throughout the world is an important macroprudential tool is also supported in Turkish case. It is understood that capital 
buffers, another macroprudential tool, are also extremely important in terms of financial stability. The positive shock in the capital buffer, expressed in terms of the capital/loans ratio according to Figure11, causes a decrease in the financial stability indicator with a 1-mounth lag, in other words, a positive contribution to financial stability. Figures12 and13, which show the effects of required reserve ratio and foreign exchange liabilities on financial stability, display that these macroprudential instruments have no significant influence on the financial stability indicator. This result should be evaluated as an opposite one to our expectations. Even if the reactions are at a very small level, they are in line with anticipated direction.

\section{Conclusion}

Our aim in this study is to test whether macroprudential policy instruments used in Turkey are indeed making a contribution to financial stability and to contribute to the literature on this issue. In addition to lack of a widely accepted definition, there is no consensus on the measurement of financial stability. In our study, first the financial stability indicator (FSI) was established taking into consideration the characteristics of the financial system in Turkey. Financial stability indicators are often composed in the form of weighted averages of a series of indicators that express the health status of the financial system. Since the banking sector in Turkey was the most important component of the financial system, it has been brought to the forefront in the creation of this stability indicator. The components used in the FSI are the banking sector indicators (BSI), the credit market indicators (CMI) and the foreign exchange market indicators (EMI).

The beginning of 2010 were accepted as the period in which our macroprudential policies are implemented in Turkey. The study period was set as 2010: January- 2017: February using the monthly frequency data. The variables used in the formation of the FSI were the banking sector asset profitability ratio, the 1-year consumer credit interest rate, the banking sector domestic credit volume and the exchange rate basket. First, the data were normalized and then the weights were estimated empirically.

Macroprudential variables which are the most prevalent in the literature have been selected in the determination of macroprudential policy tools in the second stage of the study. These contain: Limitation of banking sector credit concentration, interbank money market position, banking system leverage ratios, banking sector capital buffers, banking sector required reserves and foreign currency liabilities. The time-series representing these variables are tested for stationary by using ADF and PP tests and the results confirm that all the variables are integrated of order one. For this reason, the vector error correction model (VECM) was used in the estimation process of the model.

According to the results of the VECM model, the macroprudential tool that we use to represent credit concentration in the banking system (CONC) affects financial stability positively. The positive shock to this variable affects the financial stability indicator 
negatively. The indicator of banks money market position (INTER) and the indicator of financial stability change in the same direction. A positive shock in the net money market position caused deterioration in the indicator of financial stability. A positive shock to the leverage ratio of the banking system negatively affects the financial stability. In other words, the fact that the process of demobilization, which takes place all over the world, is an important macroprudential tool was also confirmed in Turkey. The positive shock to the capital / loans ratio, which is not capital buffering, caused a 1-month lag length in the decrease of the financial stability indicator, which is a positive contribution to financial stability. It has been determined that the required reserve ratio and the foreign exchange debt were insignificant influence on the financial stability indicator. Low values of Reserve Option Mechanism effect on financial stability emphasised a priority on regulating international reserves. Low values of the effect of foreign exchange debts on financial stability could be interpreted as a result of the effective implementation of decisions that limit the risk of exchange rate after the 2001 crisis.

As a result, the macroprudential policy instruments affect financial stability and contribute to ensure and maintain it for the special case of Turkey.

\section{References}

Brockmeijer, J., Nier, E., Kang, H., Mancini, T., Hesse, H., Columba, F., . . Vandenbussche, J. (2012). The interaction of monetary and macroprudential policies: Backround paper. IMF Working Paper.

Central Bank of the Republic Turkey. (2013). CBRT Bulletin. Ankara: CBRT.

Cerutti, E., Correa, R., Fiorentino, E., \& Segalla, E. (2016). Changes in prudential policy instruments- A new cross-country database. IMF Working Paper. https://doi.org/10.5089/9781475574517.001

Claessens, S. (2014). An overwiew of macroprudential policy tools. IMF Working Paper. https://doi.org/10.5089/9781484358115.001

Galati, G., \& Moessner, R. (2013). Macroprudential policy- a literature review. Journal of Economic Surveys, 27(5), 848-860. https://doi.org/10.1111/j.1467-6419.2012.00729.x

Jácome, L. I., Nier, E. W., Osiński, J., \& Madrid, P. (2011). Towards Effective Macroprudential Policy Frameworks: An Assessment of Stylized. IMF Working Paper.

Viñals, J., Brockmeijer, J., Moretti, M., Osinski, J., Blancher, N., Gobat, J., . . . Wu, X. (2011). Macroprudential Policy: An Organizing Framework. IMF Working Paper. 


\section{Macrothink}

\section{Copyright Disclaimer}

2018, Vol. 10, No. 2

Copyright for this article is retained by the author(s), with first publication rights granted to the journal.

This is an open-access article distributed under the terms and conditions of the Creative Commons Attribution license (http://creativecommons.org/licenses/by/3.0/). 